\title{
When Procedural Legitimacy Equals Nothing: Civil Society and Foreign Trade Policy in Brazil and Mexico*
}

\author{
Vinícius Rodrigues Vieira**
}

\section{Abstract}

Non-state actors contribute with inputs to the elaboration of the national interest in trade negotiations, thus enhancing its legitimacy. Nevertheless, does the participation of those actors necessarily equal influence on the part of all segments of civil society on policymaking? To answer the question, I argue that procedural legitimacy should be evaluated not only in relation to the inputs society provides to the State, but should also consider whether officials actually analyse societal contributions in decision-making. I demonstrate the empirical application of the model based upon Brazil's experience in multilateral trade negotiations during the 2000s, using Mexico as a shadow case. I conclude that foreign trade policymaking can only be democratised if, in procedural legitimacy, the State attributes equal weight to contributions from all types of societal actors, including civil society organisations and organised social movements, which tend to have less material resources and power than interest groups such as business associations and labour unions.

Keywords: Foreign Trade Policy, Civil Society, Legitimacy, Brazil, Mexico, Doha Round, Policymaking.

\footnotetext{
* Received on 29 October 2015 and approved for publication on 22 February 2016.

** Getúlio Vargas Foundation, São Paulo, and University of São Paulo, São Paulo, SP, Brazil; vinicius.vieira@fgv.br
} 


\section{Introduction}

The participation of non-state actors in policymaking has attracted the attention of various fields of Social Sciences, including Foreign Policy Analysis and Normative Theory. Specifically, in decisions regarding international affairs - a sphere in which strategic state interests are more frequently at odds with societal demands - the effects of such a phenomenon remain unclear. The basic consensus is that non-state participation renders foreign policy subject to the logic of any other public policy in democracies, in the terms defined by Lentner (2006), thus requiring legitimacy from societal actors. According to Barnard (2002), legitimacy in policymaking in pluralist settings should be understood in terms of procedure and substance. The former relates to legitimate decision-making (elaboration of positions), whereas the latter is associated with how well society welcomes the consequences of the positions the State takes. The definitions, however, miss a crucial point: participation, with inputs that support policymaking, do not necessarily render influence on decision-makers (Martin 2000), who may receive demands just to mitigate the eventual contestation of policies.

Thus, if procedural legitimacy is the only one that matters before the output of policymaking emerges, how is it possible to evaluate whether all inputs are considered and, thus, influence the formation of the national interest in an issue-area? Based on the literature on State-society relations regarding transnational affairs and normative debates on legitimacy and societal participation in policymaking, I argue that, in order to elucidate that question, procedural legitimacy should be reconceptualised. Such a concept must focus not only on the degree of State openness to inputs from civil society. Rather, the consideration of those inputs is a necessary condition to confer legitimacy to decision-making, concisely defined as the set routines through which individuals acting on behalf of the State attribute final shape to outputs, including public policy targeting either domestic or 
When Procedural Legitimacy Equals Nothing:

Civil Society and Foreign Trade Policy...

international issues. If existent, such consideration takes place at the analytical stage of policymaking, henceforth considered as the phase in which officials decide the positions they will take on behalf of the State.

I demonstrate the empirical application of decomposing procedural legitimacy into an input stage and an analytical one through an empirical narrative that, following the model of Beach and Pedersen (2013: 17), involves process tracing with the purpose of theory building. The narrative comprehends, first, a main case in which the State, in spite of having received inputs from civil society organisations (CSOs) and organised social movements (OSMs), did not take into account their positions in decision-making. Secondly, I enhance the conclusions of the article through the study of a shadow case (Gerring 2016) that would represent the main case's counterfactual (Lebow 2010), in which policymakers remained closed to demands from CSOs and OSMs. I consider CSOs as organisations that advocate issues on behalf of individuals and other collective actors without an explicit mandate from those vindicated. OSMs do the same, although are networks of CSOs, with the eventual contribution of interest groups. In turn, interest groups advocate issues for a defined constituency (Baur 2011; Smith 2008). That is the case of business associations and labour unions.

The experience of Brazil and Mexico in multilateral trade negotiations in the 2000s serves, respectively, as the main case and the shadow case for the analysis. During the negotiation of the Doha Development Agenda (DDA) within the framework of the World Trade Organisation (WTO), the Brazilian State-which since 2003 has had a government led by the centre-left Workers' Party (PT) - created channels to receive inputs from CSOs and OSMs. Yet the national interest reflected positions that had already been established, namely the pursuit of market access for agricultural goods in the Global North. The null effects of procedural legitimacy 
in that case are clear as Brazil's experience is contrasted with Mexico's. Under the leadership of the centre-right National Action Party (PAN) between 2000 and 2012, the country remained relatively closed to inputs from civil society, but the national interest had also been defined a priori, leaning towards liberalisation as long as it maintained a minimum level of protection for manufacturing. I thus conclude that procedural legitimacy matters to foreign trade policy, making it a democratic public policy de facto only if the State considers all contributions from society at the analytical stage of policymaking.

The research design reflects those theoretical concerns and empirical limitations. I have focussed the discussion on trade negotiations because it is an issue-area critical for testing the effects of procedural and substantial legitimacy. Such negotiations fall in the realm of foreign trade policy, combining the State-centric notion of national interest (Krasner 1978) with tangible impacts (redistribution of material gains, following domestic liberal frameworks such as Moravcsik 1998) of decisions on non-state actors, thus generating the expectation that they will attempt to influence policymaking. I have opted to employ Mexico as Brazil's shadow case for both practical and logical reasons. In practical terms, differences in the availability of primary sources for each case makes problematic a paired-comparison for the purposes of theory building, in the terms of George and Bennett (2005). For the empirical part, I rely on the triangulation of archival and secondary sources (Beach and Perdersen 2013: 123-143). While in the case of Brazil I employ 56 semi-structured interviews with policymakers and representatives from civil society (Rodrigues Vieira 2014), the same type of sources is not available for Mexico, leaving me with no other choice but to treat it as a shadow case (Gerring 2016).

Moreover, the cases share characteristics that shape State-society relations and, therefore, could render alternative narratives that, if 
not controlled, could collapse the goals of this paper. Both countries have federal systems of government and are recent democracies, as Brazilians have had regular and competitive elections with universal suffrage for President since 1989, and democratisation in Mexico happened in 1994, with the electoral reform that opened the door for de facto party competition for the Presidential office (Magaloni 2006). Moreover, after economic liberalising, they maintained relevant historical legacies from the corporatist system that emerged in parallel with the development of the Import Substitution Industrialisation (ISI) project between 1930s-1980s (Schneider 1997). At the international level, the two cases also share similarities. They are located in the same region of the world (Latin America) having gone through a process of regional integration that, in spite of differences in scope (The Common Market of the South-MERCOSUR — aims to be a customs union, while the North American Free Trade Agreement-NAFTA—is just a free-trade area), mobilised domestic actors and changed domestic preferences. By focusing only on the timeframe of the DDA negotiations, I remain faithful to the research design described above. That is the case, as the inclusion of negotiations in which the countries under scrutiny did not participate simultaneously could generate noises that would invalidate the elaboration of the empirical narrative.

The article begins with a review of the literature on State-society relations in foreign trade policy, including the debates focused on the action of CSOs and OSMs in intergovernmental organisations (IGOs) in trade. The limitations of such debates support the need to study the behaviour of collective actors at the domestic level vis-à-vis the State. To fill the gaps identified in the literature review, I discuss normative concepts related to policymaking, leading me to argue for the inclusion of the analytical stage in the study of procedural legitimacy. I then develop the empirical narratives, tracing first, for the main case (Brazil), the interaction between the 
State and non-state actors in the 2000s regarding the DDA talks, with reference to developments in trade policymaking that had taken place during the previous decade. Subsequently, I repeat the same procedures for the shadow case (Mexico). I conclude the article with suggestions for new avenues of research based on the re-conceptualisation of procedural legitimacy.

\section{Non-state actors and trade negotiations}

The centrality of the State in elaborating positions on foreign policy has certainly been challenged by the mobilisation of non-state actors in both domestic and international arenas. Nevertheless, works that analyse the role of non-state actors in world politics still fall short of accounting for the actual weight of CSOs and OSMs in the definition of national interests in issue-areas that global governance mechanisms encompass, such as trade. That is the case, because the literature does not often make a distinction between activism (that is, the provision of inputs) and influence (the actual impact of those inputs on decision-making). As demonstrated below, particularly in works focused on Latin American cases, limitations also exist insofar as the existence of formal mechanisms of State consultation with society is usually considered a sufficient condition for societal actors to influence policymaking.

According to Risse (2002: 259), much of the literature on civil society and international affairs contests a State-centred conception of world politics, stating that societal actors matter, yet without clarifying how they affect international issues, such as negotiations conducted within IGOs. In the realm of trade, participation of CSOs has become the rule rather than the exception. The WTO has been open to their participation at least since its first ministerial meeting, held in Singapore, in 1996 (O'Brien et al. 2000: 106). Yet, activists complained about the lack of clarity in the discussions, preventing 
When Procedural Legitimacy Equals Nothing:

Civil Society and Foreign Trade Policy...

them from even participating in decision-making (O'Brien et al. 2000: 96). Following the success of CSOs and OSMs in blocking the launch of the Millennium Round of multilateral trade liberalisation during the Seattle Ministerial Meeting in 1999, the WTO opened itself to civil society actors. Throughout the 2000s, during the negotiations of the DDA, launched in 2001, an increasing number of NGOs - including interest groups that represent business sectors and labour - attended ministerial meetings as observers. For instance, in the Hong Kong Ministerial Meeting, in 2005, more than 750 non-state actors, including business and labour associations, participated in open debates (WTO 2009). Moreover, private actors acquired the right to submit legal briefs on trade disputes between member-states (Steffek and Ehling 2008). Quoting those facts and similar examples involving other IGOs, Tallberg and Uhlin (2012: 215) conclude that there is an increasing participation of CSOs in global policymaking. Yet, such a conclusion is problematic insofar as the authors do not distinguish civil society activism/participation from influence.

The same problem persists in the literature focused on CSOs and other non-state actors from Latin America that joined transnational networks with the goal of influencing international issues. Fox (2001) claims that, in Mexico, there was in the 1990s a considerable growth in the number of networks CSOs established with U.S. counterparts. However, most of the influence of CSOs engaged in such linkages upon policymaking became effective only in issue-areas related to cases involving trans-border problems, particularly in environment (Fox 2001: 253). Such findings suggest that, at least until the early 2000s, CSOs still had the State-not mechanisms of global governance, including IGOs-as the main target for lobbying if they wanted to impact international-related issues. A brief analysis of CSO articulation for the negotiations of the Free Trade Area of the Americas (FTAA) corroborates the 
perception that transnational alliances produce activism, but not necessarily influence. Bülow (2010) reports that, in 1997, civil society groups from the Americas formed the Hemispheric Social Alliance (HSA) during a FTAA ministerial meeting. Nevertheless, collective transnational action was not decisive in the process that led to dismantling the negotiations. Empirical studies conclude that States put the deal aside as it was no longer in the interests of governments, or, alternatively, because domestic mobilisation against the agreement mattered more (e.g.: Nelson 2015: 9).

Both interpretations lead me to prioritise instead the domestic level in order to identify whether CSOs and OSMs influence policymaking. A group of scholars consider that democratisation automatically leads to civil society participation in policymaking. Yet, differences in the levels of participation and influence, depending on the type of policy and issue-area, are not problematised. As Batra and Otero (2007: 3) and Natal and González (2003: 854) argue in relation to the Mexican case, the corporatist system has persisted in the country even after economic liberalisation in the 1980s and democratisation in the 1990s. Thus, it seems that, for non-state actors, there is a trade-off between autonomous organisation vis-à-vis the political establishment and the capacity to influence policymaking without being co-opted by State actors, including political parties that hold office.

Beyond Latin America, the formation of public policy has also been subject to similar debates. In that regard, the European Union (EU) emerges as a critical case due to its organisation as a multilevel system that, in centring decision-making in the hands of bureaucrats and non-elected political appointees in Brussels, mitigates the chances of civil society actors having their voice effectively heard as policies are crafted. That is why, in the European context, the literature on legitimation of public policy distinguishes output 
legitimacy - related to how effective a given policy is in relation to constituencies that suffer its effects - from input legitimacy — which reflects people's participation in decision-making. Such a distinction was originally devised by Scharpf (1999) for analysing communitarian/supranational policymaking. Among the scholars that attempted to advance such a discussion, there is Schmidt (2006), who defends the need to establish consulting processes with the people. Such a debate dovetails with Barnard's (2002) notions of procedural and substantial legitimacy. As mentioned in the introduction, he argues that the former relates to the processes of rule- and decision-making, whereas the latter is associated with institutional output. However, in establishing such definitions, Barnard leaves aside the distinction between participation/activism and influence of societal actors in policymaking. If procedural legitimacy is the only one that matters in decision-making, how is it possible to evaluate whether all inputs are really considered in producing an output/policy?

To answer the question, Schmidt (2010: 7) proposes that policymaking should also be analysed in terms of throughput legitimacy, which focuses the processes between the input and output phases in terms of accountability, transparency (related to information availability), and openness to civil society. Yet those three elements do not assure that inputs from CSOs and OSMs will actually be considered in decision-making. As Martin (2000) argues in relation to American policymaking in foreign economic affairs, the fact that certain social actors are active even in-between the input and output stages does not mean that they are also influential. For instance, a given actor-be it an individual or a collective-may have more weight on final decisions despite not being very active during the formulation of a certain policy. Neither accountability nor transparency in decision-making suffice for conferring fairness on the entire process: they may just hide prior settlements, reached 
outside the realm of formal State-society interactions, such as public hearings.

Thus, should the State aim to elaborate policymaking in a legitimate manner, it has to be committed to analysing all contributions from civil society equally. By ignoring the principles that frame State officers' decision-making, the concept of throughput legitimacy does not distinguish between mere participation of societal actors in policymaking and their actual impact upon the outputs that result from such a process. Within such a framework, the study of legitimacy in policymaking - including in international affairs restricts itself to the input stage, leaving unclear whether State decisions have been set before inputs from all segments of civil society have been collected. Policymaking thus becomes nothing but a close-ended story that State-actors write alone with the eventual cooperation of a few supporters in civil society.

\section{Unfolding procedural legitimacy: input and analytical stages}

The limitations mentioned above support the central claim of the paper: procedural legitimation needs to be re-conceptualised, conceived more than the process through which inputs are gathered from society. That is the case as existent works on non-state actors' participation in trade negotiations offer incomplete conceptual tools to verify whether a State considers de facto inputs from societal actors for subsidising decision-making, and then allows those contributions to change the final shape of policies. Moreover, one has to escape the logical trap of the axiom that considers the existence of CSOs and OSMs, interested in international affairs, a sufficient condition for them to impact on policymaking in foreign-related issues. With such goals in mind, I briefly look at the concepts of justice and fairness in Normative Theory that problematize the limits 
for societal participation in politics outside partisan settings and elections.

At the core of those limits lies the difficulty of welcoming opposite worldviews in pluralistic settings. To mitigate such a problem, Habermas ([1983] 1990) defends a procedural conception of deliberation, which would lead participants to collective learning, including in what concerns State decisions. However, procedures-including openness to societal inputs—can have null effects upon decision-making if they do not '...include rules for evaluating and selecting competing claims and arguments...' (Renn, Webler and Kastenholz 1996: 47). By no means does such a claim imply that a State's decisions should be consensual: procedural justice (understood as equality in participation) tends to prevail over substantive fairness (equality in outcomes) insofar as '...various actors in society disagree about what is a just and fair solution and what ratio of payoffs and risks is regarded as acceptable' (Renn, Webler and Kastenholz 1996: 145). That is to say, since reaching a consensus on the substance of decisions appears to be unfeasible, opening policymaking to broad participation would be sufficient to legitimise policy outputs. In that case, all social actors would at least be equal in their ability to provide inputs, which is certainly a crucial step for legitimising States' decisions. ${ }^{1}$ Yet, if outputs in policymaking cannot be consensual due to disagreements among societal actors in what concerns their worldviews, decision-making may lack legitimation if it is structured in a functionalist fashion.

Therefore, although the substance of policy outputs hardly encompasses all standpoints from every single societal actor that contributes with inputs, the decision-making process can - and should-analyse all inputs, considering them as having equal weight. Thus, the analytical stage in policymaking implies considering every single contribution from society as equally valuable, regardless of the individual or type of NGO providing it. By considering the existence of the analytical stage of policymaking in procedural 
legitimacy, one can thus assess whether the State actually mitigates asymmetries of power among civil society actors. Figure 1 outlines the difference between current approaches and the model I propose, which separates the study of procedural legitimacy into two stages (input and analytical).

\section{Figure 1}

Types of Legitimacy and Stages of Policymaking

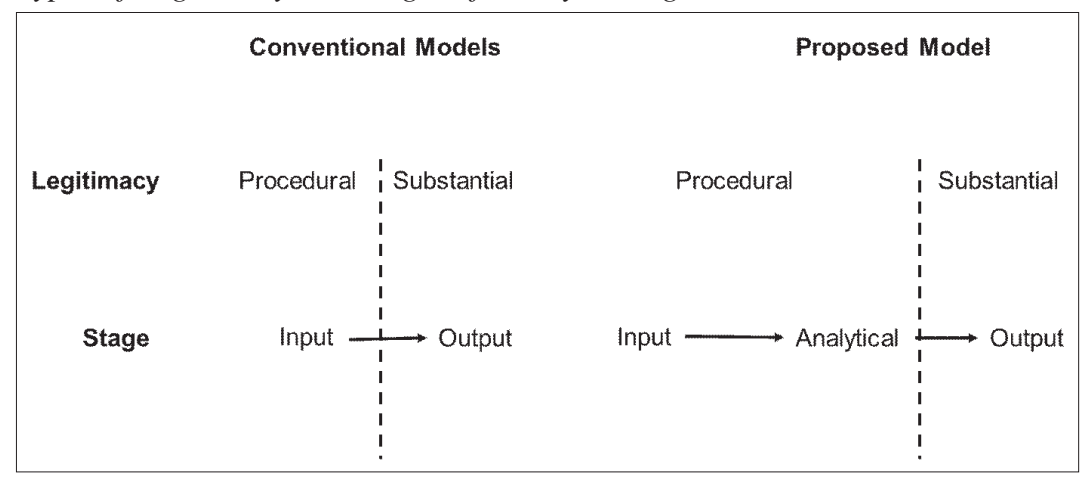

Crucial to understanding the utility of the proposed model is the distinction between different types of NGOs. In the introduction, I stated that not all NGOs are CSOs. The term NGO also comprises non-governmental actors that represent societal actors with primarily economic interests, such as business and labour. Following Baur (2011: 115-121), I elaborate a distinction between interest groups, on the one hand, and CSOs and OSMs on the other. According to her, while interest groups strive for power, CSOs (which she labels as NGOs) do not (Baur 2011: 116). Such a distinction dovetails with Smith's (2008) definition of social movements (which can be considered the same as OSMs). In contrast to interest groups, social movements:

[L]ack regular access to political institutions and the elites operating within those institutions. In contrast to interest groups, which are principally involved in promoting 
When Procedural Legitimacy Equals Nothing:

Civil Society and Foreign Trade Policy...

the material concerns of particular (and usually relatively privileged) groups within the existing political arrangement, social movements pursue more 'transformational' goals that alter power relations in society (Smith 2008: 199).

While I agree that the distinction between those two types of civil society actors is useful, I argue that it has to be defined in a more precise manner, in terms of the representation of societal actors. Thus, as mentioned in the introduction, I define CSOs as organisations that act on behalf of individuals and other collective actors without having received delegation to do so, whereas OSMs follow the same logic, being, however, networks of individuals and/or CSOs, yet not precluding interest groups from being members. In turn, interest groups advocate issues for themselves and a defined constituency, with a clear mandate from those represented. That is the case of business associations and labour unions, even if at their origin they had strong links with the State, as is the case in Latin America. Therefore, I suspect that interest groups tend to be more influential than CSOs and OSMs in the making of foreign trade policy as the former own more material resources.

Therefore, while inputs from interest groups (in particular business) are more likely to be welcomed by the State, contributions from CSOs and OSMs tend to be downplayed, notwithstanding their consideration in the input phase of policymaking. Such a statement implies that the format of the procedures through which civil society provides inputs to States does still matter for elaborating legitimate policies. Nevertheless, while input legitimacy - which consists of welcoming contributions from non-state actors - is a necessary condition for policy legitimation, it does not suffice for producing such an outcome. Echoing Martin's (2000) distinction between activism and influence, I claim that legitimacy in policymaking only 
arises if CSOs and societal actors in general are able to influence the output of policymaking once they opt to provide inputs to State actors. This is possible only if the analytical stage of policymaking is present, which, in turn, only exists whenever civil society's positions are de facto considered, since decision-making takes place in a given issue-area, such as foreign trade policy. ${ }^{2}$ Based on this, I expect that all civil society actors providing inputs to policymaking are influential only whenever procedural legitimacy is not restricted to the input phase, but also encompasses the analytical stage.

To mitigate the inequality of resources between interest groups, on the one hand, and CSOs and OSMs, on the other, the analytical stage has to be in place. Isolated, the input stage does not suffice for legitimising policymaking, thus rendering procedural legitimacy as void. Table 1 summarises how procedural legitimacy can be unfolded and how its two stages affect the ability of different types of civil society actors to influence the formation of positions in foreign trade policy.

\section{Table 1}

Stages of Procedural Legitimacy and Participation of Civil Society

\begin{tabular}{llll}
\hline Stage & Interaction & Example & Expectation \\
\hline Input & State-Society & $\begin{array}{l}\text { Consultative councils with } \\
\text { civil society }\end{array}$ & $\begin{array}{l}\text { All participate, but interest } \\
\text { groups tend to be stronger }\end{array}$ \\
Analytical & Intra-State & $\begin{array}{l}\text { Disposition in using inputs } \\
\text { from all societal actors }\end{array}$ & $\begin{array}{l}\text { CSOs and OSMs } \\
\text { counterbalance interest groups }\end{array}$ \\
\hline
\end{tabular}

The concept of the analytical stage implies a rationale diverse from Schmidt's (2010) notion of throughput legitimacy. While the latter would depend only upon accountability, transparency, and openness to civil society- as detailed in the previous section - the forms also stem from an ethical commitment of officers in intra-State interactions as they analyse the potential policy outputs, such as different options for expressing the national interest in trade. Certainly, transparency and accountability contribute to reducing the 
possibility of bias in the analysis of inputs from societal actors with different levels of power, but is far from a sufficient condition for avoiding unequal weight among them in decision-making. In sum, the distinction between input and analytical stages in procedural legitimacy avoids ignoring the logical hypothesis that fairness in gathering opinions from different societal groups does not imply that the same concern is present, since the output (i.e. policy) gains its final shape through the hands of State officers responsible for decision-making.

\section{Building the narrative}

With the distinction between the input and analytical stages within procedural legitimacy in mind, I now elaborate the narratives of Brazil's and Mexico's State-society relations in the context of defining the national interest in trade negotiations during the DDA timeframe. The goal of studying these two countries is to demonstrate that the mere existence of inputs coming from all types of NGOs does not suffice for producing a policy with procedural legitimacy. I then trace interactions between non-state actors and the main bureaucracy involved in the making of foreign trade policy for multilateral negotiations in the 2000s. In Brazil, the Ministry of Foreign Affairs (Itamaraty) was in charge of this duty, whereas in Mexico it was in the hands of the Department of Economy (Secretaría de Economía). In doing so, I verify whether, as argued in the previous section, interest groups (such as business associations and labour unions) are more likely than CSOs and OSMs to have their inputs considered in foreign trade policy. Empirical elements that corroborate such a proposition are essential for the construction of a narrative demonstrating that procedural legitimacy counts for nothing in democratising State-society interactions if policymakers welcome inputs, yet do not attribute to them the same weight when deciding the final shape of polices. 
As summarised in table 2, CSOs and OSMs that follow foreign trade policy in Brazil have had channels to provide inputs to the State since 2003, with the PT's ascension to the Presidency under former union leader Luiz Inácio Lula da Silva (2003-2011). Therefore, if the existence of inputs would suffice for characterising the existence of procedural legitimacy in policymaking, one could have expected that Brazil's interest in the DDA negotiations might have leaned towards protectionism - the main demand of CSOs and OSMs in that country. Yet, the country persisted on the long-standing defence of agricultural liberalisation - a goal, among others, that led Brazil to reduce the emphasis in potential agreements, other than those at the multilateral level, such as the FTAA and the MERCOSUR-UE, as they did not offer substantial gains for the commodity-exporting sector. In spite of not welcoming inputs from CSOs and OSMs, Mexico followed a similar pattern, although, in contrast to Brazil, the country was under a centre-right government, inaugurated by Vicente Fox (2000-2006) and continued by his successor, Felipe Calderón (2006-2012), both from the PAN. The pursuit of potential gains for large corporations, particularly in the manufacturing sector, and the liberalisation of agriculture and services prevailed. As in the Brazilian case, the State had defined the national interest beforehand with the participation of interest groups.

\section{Table 2}

Expected Scenarios for Inputs from CSOs and OSMs to Foreign Trade Policy-Brazil and Mexico in the DDA (2000s)

\begin{tabular}{llll}
\hline Country & $\begin{array}{l}\text { Input from CSOs and } \\
\text { OSMs? }\end{array}$ & $\begin{array}{l}\text { Expectation for CSOs } \\
\text { and OSMs }\end{array}$ & $\begin{array}{l}\text { Expectation holds after } \\
\text { empirical analysis? }\end{array}$ \\
\hline Brazil & Yes (after 2003) & Influential & No \\
Mexico & No & Non-Influential & Yes \\
\hline
\end{tabular}

The narrative, thus, demonstrates the empirical validity of the argument that procedural legitimacy equals nothing for civil society if the analytical stage of policymaking does not take seriously all 
When Procedural Legitimacy Equals Nothing:

Civil Society and Foreign Trade Policy...

civil society contributions. In both cases, the order of the narrative is the same: I begin with the main bureaucracy involved in the making of foreign trade policy in the 2000s. I then explore the brief history of State-society interactions for formulating foreign trade policy since the 1990s, with reference to the negotiations on the FTAA - in which both countries were involved - the MERCOSUR-EU agreement (for Brazil) and the NAFTA (for Mexico). Such digression allows me to identify the prevalence of interest groups over CSOs and OSMs and, thus, of economic interests over social demands in the making of the foreign trade policy of Brazil and Mexico, even in the 2000s. Finally, yet importantly, I make special reference to the activism - but lack of influence - of two OSMs that attempted to reduce the State's liberalising impetus: The Brazilian Network for People's Integration (REBRIP), in Brazil, and the Mexican Action Network on Free Trade (RMALC), in Mexico. Interviews not directly quoted still substantiate the facts narrated below.

\section{The main case: Brazil}

Itamaraty had already exchanged information with non-state actors before the beginning of Lula's government in 2003, often through ministries other than the foreign affairs portfolio. For instance, Carvalho (2003) reports the existence of interactions between policymakers, on the one hand, and interest groups, on the other, for elaborating the national positions to be defended at the Seattle Ministerial, in 1999. In July of that year, four months before the Seattle Ministerial Meeting that would have launched the Millennium Round, President Fernando Henrique Cardoso (1995-2003), from the Party of Brazilian Social Democracy (PSDB), created the Inter-Ministerial Working Group on International Trade of Goods and Services (GICI). The group focused on liberalisation at the multilateral level (Presidência da República 1999), but also dealt with other negotiations, such as the talks for establishing the FTAA 
and the MERCOSUR-EU bilateral agreement. Apart from Itamaraty, the GICI had as members the ministries of Finance, Development, Industry, and Foreign Trade (MDIC); Agriculture (MAPA); Science and Technology; Budget and Public Management; and Environment, as well as the Chamber of Foreign Trade (CAMEX), which had been created in 1995 to coordinate policymaking in the field, yet never displaced Itamaraty as the main bureaucracy for defining positions in foreign trade policy (Ramanzini Júnior and Farias 2014: 177).

Itamaraty's centrality in formulating negotiating positions for trade talks persists in spite of the emergence of new actors within both State and society interested in contributing to policymaking in the field. As Faria, Lopes, and Casarões argue (2013: 468), bureaucrats who belong to the Ministry arrogate to themselves a monopoly in defining the national interest. Yet at least in terms of negotiations on trade-related matters, the diplomatic body had adapted itself since the mid-1990s to receive inputs from other bureaucratic units. The major factor in triggering challenges to Itamaraty's status as the main bureaucracy in trade negotiations was the creation of MERCOSUR, signed in 1991 and effective since 1995. Yet, as Vigevani et al. (2008) explain, the formation of the bloc and its subsequent development in the 1990s remained a State-centric, elite-driven project, eventually influenced only by interest groups while keeping CSOs and OSMs apart. The same patterns are verified in the non-regional and bilateral negotiations launched after mid-1990s. Industry had been mobilised for systematically following trade negotiations at least since 1996, when the Brazilian Business Coalition (CEB) - led by the National Confederation of Industry (CNI) - was formed following the demand posed by the launch of the negotiations of the FTAA in 1994 (Mancuso and Oliveira 2006), as well as of the MERCOSUR-EU talks, which began in 1995.

Under Lula's government the Brazilian State built several channels of communication with civil society actors to formulate foreign trade 
When Procedural Legitimacy Equals Nothing:

Civil Society and Foreign Trade Policy...

policy (Carvalho 2010). One of them was dedicated purely to agriculture with the aim of building consensual positions related to the sector, which was the Brazilian focus in the Round (Bureaucrat A 2012). Called the Informal Technical Group (GTI), it included the participation of players from the field of the State other than Itamaraty and interest groups in agribusiness (Bureaucrat A 2012; Carmona 2012). The GTI was built upon the pre-existing connections between the MAPA and market actors in State-society chambers organised to discuss policies for the sector (Cozendey 2012; Sande 2012). The evidence suggests that the group surpassed the GICI as the main forum for formulating Brazil's core positions for the DDA negotiations. As diplomats report, many positions that would later be presented at the negotiations by the Agricultural G-20 - a coalition of countries that aimed to liberalise agriculture at the multilateral level - were first discussed at the GTI (Bureaucrat A 2012; Senior Bureaucrat 2012). Moreover, Itamaraty contributed to the creation of the ICONE, which improved negotiators' technical background and contributed to the G-20 (Nassar 2012).

A similar approach was taken for the industrial sectors. Itamaraty created a group analogous to the GTI for Non-Agricultural Market Access (NAMA) themes, in particular manufacturing tariffs (Lohbauer 2012; Market Actor A 2012). Also, at the beginning of 2004, the Brazilian Permanent Mission at the WTO pressed FIESP to expand its research capacity on international negotiations (Market Actor A 2012; Meira 2012). Diplomats in the Permanent Mission wanted to build critical mass to negotiate NAMA, and, despite initial opposition from top-tier diplomats based in Brasília, the Federation of Industries of the State of São Paulo (FIESP) appointed an officer to work with the Brazilian representatives to the WTO (Market Actor A 2012). FIESP's role - which acted outside of the CEB's scope due to the weight of São Paulo's manufacturing segment in the national industrial production - as an informal think-tank for negotiations 
involving goods under the NAMA rubric was crucial insofar as the MDIC opposed the trade-off that the DDA implied for Brazil. As the Round seemed to be reaching its end, in 2008, the Permanent Mission liaised directly with sectorial and sub-sectorial associations to discuss the impact of tariff cuts and the selection of tariff lines for an exception list in NAMA (Meira 2012; Market Actor A 2012). The MDIC was also consulted in the process.

Aside from the GTI, Itamaraty had at least one other collegiate body that contributed to determining negotiating positions for the DDA talks: the Subgroup on Services at the GICI (GICI-SV) (Cozendey 2012). As seen before, with the creation of the GTI in 2003, the GICI lost relevance. So did the GICI-SV, which was concerned with other WTO-related issues and the MERCOSUR (Controladoria-Geral da União 2005). At least until 2004, the GICI-SV also dealt with the MERCOSUR-EU talks as well as with the FTAA negotiations (Marega 2004: 4). According to a list of participants of a GICI-SV meeting in September 2004, the subgroup had 58 members. Of these, only 15 (25 percent) were non-state players, such as business associations and labour unions (CNA 2012), some of which integrated with the REBRIP. It may be classified as an OSM, being a coalition of civil society organisations with an anti-liberalising orientation that lobbied the government to adopt protectionist measures in the DDA negotiations (Oliveira 2013: 192-200). Just 33 GICI-SV members (57 percent of the total) sent representatives to attend the meeting (CNA 2012). With such a large group dominated by State actors (including ministries, bureaucratic agencies, and State-owned companies), it is unlikely that substantial positions that Itamaraty had not defined beforehand were actually discussed (Market Actor B 2012; Lohbauer 2012).

However, not all agricultural segments defended further liberalisation. Dairy, non-tropical fruits, rice, and vegetable producers were the sectors potentially opposed to tariff reduction at 
When Procedural Legitimacy Equals Nothing:

Civil Society and Foreign Trade Policy...

both bilateral and multilateral levels (Rodrigues Vieira 2014). Despite their protectionist interests, they did not constitute relevant sectorial associations to lobby the government. Their demands, as well as those from subsistence farmers, were channelled through the CONTAG and other NGOs that formed the REBRIP. The Central Union of Workers (CUT), the largest labour federation in Brazil and a historical ally of Lula's PT, was also part of the REBRIP and commissioned studies on the impact of the DDA on the labour market (Barbosa 2007; Instituto Observatório Social and Lasos 2008). In 2008, when the DDA reached a position of stalemate, all major parties at the negotiating table-Brazil, the EU, India, and the US - had agreed to include special safeguard measures (SSMs) that granted the right to States to lift temporary trade barriers to protect small farmers from import surges. This was a core demand from the CONTAG and REBRIP representatives, which suggests, at a first glance, that they managed to convert participation into influence. However, the scope of SSMs that Brazil embraced was narrower than the REBRIP had sided with, not to mention that manufacturing tariffs would have been reduced below what protectionist groups from both the market and civil society were expecting. Not, coincidently, those sectors which claimed, behind the scenes, that the deal had been 'rammed down their throats', as a member of a key interest group reports (Market Actor A 2012).

Moreover, the REBRIP acted against the liberalisation of public services, including energy and water supply, education, and health (REBRIP 2014) - issues which were eventually left aside in the negotiations, along with discussions on intellectual property. Brazil, in fact, did not consent to discussing services not because of REBRIP's activism, but in spite of it. Evidence indicates the existence of well-articulated offensive interests in the services sector, particularly in construction and information and communication technology (ICTs) (Bureaucrat B and Bureaucrat C 2012; IBM 2006; IT Web 2007). Due to the lack of a unified sectorial 
lobbying body (like the National Confederation of Agriculture CNA - and the CEB/CNI and FIESP in industry), the services sector, as a whole, was not be expected to have as much power as other sectors. Nevertheless, as the negotiations for the sector in the DDA were broken down into separate offers to groups of trade partners on specific issues, there was room for attending the demands of specific service-related segments. In such a scenario, one would thus expect that the Brazilian government would have been more active in the negotiation of services, expressing offensive positions on behalf of construction and ICTs.

Yet, as MDIC's officials report (Bureaucrat B and Bureaucrat C 2012), Itamaraty preferred to use services as an eventual bargaining currency for pursuing the major goal of Brazilian diplomacy in the DDA: agricultural liberalisation to enhance the country's gains in material terms through the expansion of commodity-exports (DELBRASGEN 2004). At the same time, under Lula's government, such an approach was converted into a means of enhancing Brazil's leadership among developing countries (Burges 2009: 160-161). In addition, the country aimed to increase its prestige at the international level by citing as evidence the protectionist agricultural interests of the Global North (Narlikar and Hurrell 2006). In such a scenario, inputs from CSOs and OSMs were only useful for the State and government as long as those contributions matched the political-economic goals that had already been set. The existence of procedural legitimacy for actors other than interest groups and labour, thus, did not suffice for legitimising policymaking, as contributions from that part of civil society were in practice not taken into account in the analytical stage of policymaking.

\section{Shadow case: Mexico}

As with Brazil, Mexico pursued a liberalising agenda for agriculture, blended with limited opening of the market for manufactured goods 
(Ortiz Mena 2003: 3-4). In addition, Mexican negotiators expressed interest in opening markets in services. Those positions, in general, satisfied interest groups and most organised labour, being, however, against the demands of CSOs and OSMs, in particular the most prominent of the latter, the RMALC. Thus, as in Brazil, evidence strongly suggests that there was no broad civil society participation in foreign trade policymaking for the DDA. Yet, in contrast with the Brazilian case, such an outcome was expected as Mexico did not have formal consultative mechanisms with CSOs other than with those segments that formed economic interest groups, representing either business or labour.

In 2008, the Advisory Council for International Trade Negotiations (CANCI) was reformed (Mexico 2008). The Council is attached to the Department of Economy, which has been in charge of representing Mexico in trade talks since 2000. Nevertheless, changes in the composition did not assure the participation of societal actors who were not directly associated to economic issues, although incorporation of CSOs and OSMs into trade policymaking had been considered at least since 2002 (Alba and Vega 2002: 72). In fact, with the victory of PAN's presidential candidate Vicente Fox in 2000, the first politician non-affiliated to the Institutional Revolutionary Party (PRI) to lead the country in 71 years, civil society expected further opening to CSO and OSM participation in the making of foreign trade policy. However, Fox's government maintained the same practices, inaugurated during PRI administrations in the 1980s and 1990s, as Mexico liberalised its economy and signed international economic agreements (Natal and González 2003: 859 and 861). So did Calderon's administration after 2006, as the restricted reform of the CANCI suggests.

The CANCI had been created at the end of 1993, just before the NAFTA provisions came into force, in 1994. According to the document that created the Council, it aimed to give technical support 
to the Department of Commerce and Industry Support (SECOFI), then in charge of conducting trade negotiations on Mexico's behalf and the predecessor of today's Department of Economy. Apart from the Secretary as head of SECOFI (who presides the council), it was composed of the Subsecretary of International Trade Negotiations, a General Coordinator and at least a representative from each of the following sectors: academia, agriculture, labour, and business (Mexico 1993: 1). There was also the provision to create regional councils with members handpicked by the Secretary of Commerce (Mexico 2003: 1). The government, however, had already consulted with the business community to create the free trade zone with Canada and the US. To legitimate the NAFTA negotiations, the government formed the Coordination of Business Organisations in Foreign Trade (COECE) in June 1990, gathering 14 business associations from various economic sectors and chambers of commerce (Witker and Hernández 2008: 418). COECE members formed - along with State actors and experts - working groups devoted to aspects of specific sectors and issues on which the deal would impact (Alba and Vega 2002: 67).

The COECE participated in the NAFTA negotiations through the Advisory Council for the NAFTA Negotiations. Having been founded in September 1990, following the recommendation of the Mexican Senate, the Advisory Council had business representatives (including the COECE itself) among its members, covering sectorial associations and trade chambers (Torres 2001: 137; Witker and Hernández 2008: 418). Apart from representatives from the sectors invited to the CANCI, the Council included the participation of representatives of large companies. Alba and Vega (2002: 65) report that labour unions were represented by the Confederation of Mexican Workers (CTM) and the National Peasant Confederation (CNC), both of which emerged during the corporatist rule of the PRI, then holding the presidency (Natal and González 2003: 854). 
Agriculture, in turn, expressed its voice through the National Confederation of Smallholders (CNPP). As was the case with the CTM and the CNC, the CNPP had been controlled by the PRI for years, suggesting that the government opened itself only to inputs from non-state actors that, for sure, would not contradict the pace of liberalisation the national authorities had set (Natal and González 2003: 854).

Yet, organised labour had room for acting outside the governmental umbrella and the corporatist straightjacket. Of all the segments of civil society, labour had been mobilised even before NAFTA came into force in 1994, as unions joined an anti-sweatshop movement in the 1980s with their counterparts in the US, Canada, Central America and the Caribbean (Saguier 2011: 185). For instance, when Mexico joined the General Agreement on Tariffs and Trade (GATT) in 1986, two main organisations, the CTM and the Labour Council (CT), were sceptical about the benefits that the multilateral regime would bring to the country and its labour force (De la Madrid 2015). Such activism emerged amid the pursuit of more autonomy in politics vis-à-vis the old corporatist system (Natal and González 2003: 858). Nevertheless, evidence suggests that unions did not strongly oppose negotiations after the establishment of the NAFTA, as it is the case of the FTAA talks (Natal and González 2003: 863). One would not be exaggerating by saying that scepticism from labour, CSOs, and OSMs stemmed from the lack of transparency of NAFTA and the negotiation of other foreign trade deals. Alba and Vega (2002: 68-69) contend that, in the discussions between Mexican negotiators and their American and Canadian counterparts, the government thought that information on the state of negotiations should be diffused in a limited and cautious manner, being made transparent only once a deal had been reached.

Thus, without influencing decision-making at the national level, little wonder that CSOs and social movements placed their efforts in 
activism at the transnational level. According to Saguier (2011: 189), the transnational networks among North American unions in the context of NAFTA prompted the formation of the RMALC. Having been created in 1991 (Ortiz Mena 2003: 2), a year before the final talks for establishing the agreement, the RMALC is analogous to the Brazilian REBRIP, comprising not only labour unions, but also peasant, indigenous, and environmental CSOs (Natal and Gonzalez 2003: 860), as well as academics focused on contesting the model of economic liberalisation. However, in contrast to the REBRIP in Brazil, the RMALC in Mexico was never integrated into formal consultation mechanisms for substantiating the formulation of national positions for trade negotiations in the 1990s and 2000s. Faced with those limitations, the RMALC, along with other OSMs, joined CSOs and movements in Canada and the US to lobby in the NAFTA negotiations. The same approach was taken in regards to civil society elsewhere to counter the liberalising trends expressed in agreements such as the FTAA and the Global Action (Bustamante 2004: 2-4; Natal and Gonzalez 2003: 859 and 882). In fact, civil society tends to be active regardless of the level of influence it manages to build vis-à-vis policymakers. In the beginning of the 2000s, there were at least nine large CSOs and/or OSMs other than the RMALC active in following trade negotiations (Natal and Gonzalez 2003: 860). Moreover, CSOs, with the support the Catholic Church, organised in Mexico an informal referendum on the FTAA between October 12, 2002 and March 18, 2003. Out of two million participants, a considerable proportion of voters (900,000) supported the Agreement (Saguier 2011: 192).

The Mexican state, however, remained closed to inputs from segments without business and/or corporatist linkages, even in contexts in which informal State-society exchanges could have taken place, as was the case of negotiation meetings with diplomats representing other countries (Bustamante 2004: 2). Evidence of the persisting closed nature of the Mexican State to inputs from CSOs 
and OSMs can be found in the negotiations of the Transpacific Partnership (TPP), concluded in October 2015. The definition of the national interest for the talks remained closed to societal inputs except those from business interest groups (Villamar 2015). Moreover, in the light of the Brazilian case, one may conclude that the mere existence of the input stage would not have necessarily implied a procedural legitimacy in foreign trade policy for multilateral negotiations. To exist de facto, procedural legitimacy requires an effective analytical stage in which the State considers all inputs from societal groups.

\section{Conclusion}

This article has claimed, based on a narrative of the experiences of Brazil and Mexico in formulating the national interest on trade negotiations during the DDA timeframe, that receiving inputs from civil society actors does not suffice for a State to provide procedural legitimacy to policymaking. Under the PT government, at the input stage of foreign trade policymaking, the Brazilian State opened itself to contributions from CSOs and OSMs, yet, as in Mexico - where there were no channels for the State to communicate with those types of civil society actors - contributions did not change the positions the government had initially set. From this, I conclude that the existence of the analytical stage is also a necessary condition for opening decision-making in foreign affairs not just to interest groups, but also to CSOs and OSMs, and, thus, to promote democratisation de facto in the definition of national interests in external affairs. Once those two stages (input and analytical) are de facto functioning, non-state actors other than those associated only with economic cleavages, may go beyond mere activism/participation to actual influence on policymaking.

The conceptualisation effort advanced in this article leads to two main avenues of research. The first consists of analysing public 
policies other than foreign trade policy, to verify whether procedural legitimacy alone equals nothing for CSOs and OSMs. Needless to say, interest groups, particularly those formed by business, have an intrinsic relationship with State actors - be they bureaucrats or elected politicians - not only in recent democracies such as Brazil and Mexico, but also in the so-called advanced industrial societies. The second avenue leads to the verification of the applicability of this typology in other trade negotiations, including agreements that have been left aside (e.g. FTAA), that are still under negotiation or have just been concluded (MERCOSUR-EU, in the case of Brazil, and TPP, in the case of Mexico). Notwithstanding the emergence of transnational networks of CSOs and OSMs, the State is still the core place for lobbying. Indeed, at least in the Brazilian case in the FTAA, preliminary evidence suggests that procedural legitimacy was preconditioned to the maintenance of the government's preferences. The Agreement, which was in the interests of industrial sectors, never came into force in large part due to the Brazilian government's negotiating tactic of postponing substantial decisions until even the US had abandoned the project, in 2005. In part, these tactics met the PT's anti-American stance in foreign policy (Rodrigues Vieira 2014). In fact, as Oliveira and Milani (2012: 388) argue, the REBRIP had far more space in the formulation of positions for the FTAA - in which OSM's perceptions converged with the government's views - than for the DDA talks.

An additional line of research falls out of the scope of the traditional agenda that analyses State-society relations, problematising the dynamics of party politics and its impact upon civil society from a historical perspective. The fact that the leftist PT in Brazil built-up consultative mechanisms whereas the rightist PAN in Mexico did not, yet both ended up in a scenario in which the State and interest groups prevailed in shaping the national interest in trade negotiations, casts doubts on whether left-wing governments-such as those that emerged in the 2000s in Latin America-really 
When Procedural Legitimacy Equals Nothing:

Civil Society and Foreign Trade Policy...

empower social demands. Echoing the first avenue of investigation I proposed, it is plausible to hypothesise that the capture of the State by business interest groups is independent from the ideological orientation and allegiances to constituencies of the political party that provides the executive. Alternatively, the State may prevail in contexts pervaded by a legacy of corporatism and, thus, dominance over civil society as whole. In such circumstances, legitimation and democratisation of policymaking in foreign affairs can hardly flourish unless CSOs and OSMs effectively shield themselves from State co-optation and instrumentalisation.

\section{Acknowledgements}

The author would like to thank the comments of participants in seminars, held between 2012 and 2015 at the University of Oxford and the University of São Paulo, on earlier drafts, particularly Andrew Hurrell, Cristiane Lucena, and Flávio Pinheiro, as well as the editors and two anonymous reviewers for their inputs to earlier drafts and versions of the argument here developed. This research has been possible due to funding from Oxford, Santander Grants, and the São Paulo Research Foundation (FAPESP, postdoctoral grant 2014/26455-7).

\section{References}

Alba Vega, Carlos and Gustavo Vega C. 2002. 'Mecanismos de Consulta Comercial en México', in Banco Interamericano de Desarrollo (ed), El proceso de formulación de la política comercial -Nivel uno de un juego de dos niveles: Estudios de países en el Hemisferio Occidental, Documento de Divulgación 13, Washington, DC: BID, pp. 63-74.

Barbosa, Alexandre de Freitas. 2007. 'Le Cycle de Doha: Impact sur l'emploi au Brésil', Travail: Capital et Société 40 (1/2): 190-221. 


\section{Vinícius Rodrigues Vieira}

Barnard, Frederick M. 2002. Democratic Legitimacy: Plural Values and Political Power. Montréal: McGill-Queen's University Press.

Bartra, Armando and Gerardo Otero. 2007. 'Rebeldía contra el globalismo neoliberal y el TLCAN em el México rural: ¿del Estado corporativista a la formación político-cultural del campesinado?' Textual: Análisis del Medio Rural Latinoamericano (50): 1-33.

Baur, Dorothea. 2011. NGOs as Legitimate Partners of Corporations: A Political Conceptualisation. New York: Springer.

Beach, Derek and Rasmus Brun Pedersen. 2013. Process-Tracing Methods: Foundations and Guidelines. Ann Arbor: University of Michigan Press.

Beer, Christopher Todd, Tim Bartley and Wade T. Roberts. 2012. 'NGOs: Between Advocacy, Service Provision, and Regulation', in David Levi-Faur, (ed), The Oxford Handbook of Governance, Oxford: Oxford University Press. pp. 323-338.

Bülow, Marisa Von. 2010. 'Civil Society and Trade Negotiations: Constructing a New Field of Action in the Americas', RCCS Annual Review 2: 1-22. Avalilable <http://rccsar.revues.org/233> [Accessed 16 Oct 2015].

Bureaucrat A. Interviewed by: Author (12 Mar 2012).

Bureaucrat B. Interviewed by: Author (27 June 2012).

Bureaucrat C. Interviewed by: Author (5 July 2012).

Burges, Sean W. 2009. Brazilian Foreign Policy after the Cold War. Gainesville: University Press of Florida.

Bustamante, Norma Castañeda. 2004. 'Mecanismos de Consulta en los Procesos de Libre Mercado en México'. Equipo Pueblo. Available $<$ http://www.equipopueblo.org.mx/publicaciones/ponencias/descargas/dcipo _mecon.pdf> [Accessed 16 Oct 2015].

Carmona, Luiz. Interviewed by: Author (19 June 2012).

Carvalho, Maria Izabel Valladão de. 2003. 'Estruturas Domésticas e Grupos de Interesse: a Formação da Posição Brasileira para Seattle', Contexto Internacional 25 (2): 363-401.

2010. 'Condicionantes Internacionais e Domésticos: o Brasil e o G-20 nas Negociações Agrícolas da Rodada Doha’, Dados 53 (2): 405-445. 


\section{When Procedural Legitimacy Equals Nothing: \\ Civil Society and Foreign Trade Policy...}

CNA (Confederação Nacional de Agricultura). 2012. 'Arquivos Referentes à Rodada Doha da OMC'. Brasília, Brazil.

Controladoria-Geral da União. 2005. 'Tomada de Contas Anual: Relatório 174798 (Secretaria de Direito Econômico/MJ)'. Available <http://www.cgu.gov.br/relatorios/RA174798/RA174798.pdf> [Accessed 27 February 2014].

Cozendey, Carlos. Interviewed by: Author (26 June 2012).

De la Madrid, Miguel. 2015. 'Adhesión de México al GATT'. Available <http://www.mmh.org.mx/nav/node/577> [Accessed 14 Aug 2015].

DELBRASGEN (Missão Permanente do Brasil em Genebra). 2004. 'Carta de Genebra', June.

Faria, Carlos Aurélio Pimenta de, Dawisson Belém Lopes and Guilherme Casarões. 2013. 'Itamaraty on the Move: Institutional and Political Change in Brazilian Foreign Service under Lula da Silva's Presidency (2003-2010)', Bulletin of Latin American Research 32 (4): 468-482.

Fox, Jonathan. 2001. 'Evaluación de las Coaliciones Binacionales de la Sociedad Civil a partir da la Experiencia México-Estados Unidos', Revista Mexicana de Sociología 63 (3): 211-268.

Gerring, John. 2016. Case Study Research: Principles and Practices. 2 ed. Cambridge: Cambridge University Press.

Habermas, Jürgen. [1983] 1990. Moral Consciousness and Communicative Action. Cambridge, MA: MIT Press.

Hurrell, Andrew and Amrita Narlikar. 2006. 'A New Politics of Confrontation? Brazil and India in Multilateral Trade Negotiations', Global Society 20 (4): 415-433.

IBM (2006) Letter (14/06/2006). Box XCOI - Jan/Dec 2006. Ministério das Relações Exteriores, Brasília, Brazil.

Instituto Observatório Social and Lasos. 2008. 'Relatório Final de Pesquisa: Impactos das Negociações de NAMA sobre o setor Metalúrgico na Argentina e no Brasil'. Available < http://www.cnmcut.org.br/sgc_data/conteudo/ \%7B3DF2B6E0-CA96-4B70-91A7-22F152A2DF8F\%7D_fitim_doc.doc> [Accessed 17 April 2014]. 
International Trade Centre. 2015. 'Mexico: Trade Policy Consultation Mechanisms'. Available < http://www.intracen.org/Mexico-trade-policyconsultation-Mechanisms/> [Accessed 16 Oct 2015].

IT Web. (2007) 'Brasscom e IBCD confirmam fusão'. Available $<$ http://itweb.com.br/29515/brasscom-e-ibcd-confirmam-fusao/> [Accessed 14 April 2014].

Krasner, Stephan N. 1978. Defending the National Interest: Raw Materials Investments and U.S. Foreign Policy. Princeton, NJ: Princeton University Press.

Lebow, Richard Ned. 2010. Forbidden Fruit: Counterfactuals and International Relations. Princeton, NJ: Princeton University Press.

Lentner, Howard H. 2006. 'Public Policy and Foreign Policy: Divergences, Intersections, Exchange', Review of Policy Research 23 (1): 169-181.

Lohbauer, Christian. Interviewed by: Author (16 June 2012).

Magaloni, Beatriz. 2006. Voting for Autocracy: Hegemonic Party Survival and its Demise in Mexico. Cambridge: Cambridge University Press.

Mancuso, Wagner Pralon and Amâncio Jorge de Oliveira. 2006. 'Abertura Econômica, Empresariado e Política: Os Planos Doméstico e Internacional', Lua Nova 69: 147-172.

Marega, Flavio. 2004. 'Trade in Services Negotiations: The Experience of Brazil'. Available <http://siteresources.worldbank.org/INTRANETTRADE/ Resources/Topics/Services/MaregaExperience1922d-Presentation.pdf> [Accessed 27 Feburary 2014].

Market Actor A. Interviewed by: Author (18 June 2012).

Market Actor B. Interviewed by: Author (4 June 2012).

Meira, Frederico. Interviewed by: Author (2 Aug 2011).

Martin, Lisa L. 2000. Democratic Commitments: Legislatures and International Cooperation. Princeton, NJ: Princeton University Press.

Mexico. 1993. 'Acuerdo por el que se Crea el Consejo Asesor para las Negociaciones Comerciales Internacionales (Publicado em el Diario Oficial de la Federación el 27/12/1993)' . Available < http://www.economia.gob.mx/files/ marco_normativo/A28.pdf $>$ [Accessed 14 Aug 2015]. 


\section{When Procedural Legitimacy Equals Nothing: Civil Society and Foreign Trade Policy...}

2008. 'Acuerdo por el que se reestructura el Consejo Asesor para las Negociaciones Comerciales Internacionales'. Available <http://dof.gob.mx/ nota_detalle.php?codigo $=5044666 \&$ fecha $=12 / 06 / 2008>$ [Accessed 16 Oct 2015].

Moravcsik, Andrew. 1998. The Choice for Europe. Social Purpose and State Power from Messina to Maastricht. Ithaca: Cornell University Press.

Nassar, André. Interviewed by: Author (20 July 2012).

Natal, Alejandro and Tonatiuh González. 2003. 'La Participación de la Sociedad Civil en Procesos de Integración Comercial: El Caso del Alca em México', Foro Internacional 43 (4): 852-892.

Nelson, Marcel. 2015. A History of the FTAA: from Hegemony to Fragmentation in the Americas. New York: Palgrave.

O’Brien, Robert, Anne Marie Goetz, Jan Aart Scholte and Marc Williams. 2000. Contesting Global Governance: Multilateral Economic Institutions and Global Social Movements. Cambridge, UK: Cambridge University Press.

Oliveira, Ivan Tiago Machado. 2013. A Política Comercial Externa Brasileira: Uma Análise de Seus Determinantes. São Paulo: Saraiva.

Oliveira, Ivan Tiago Machado and Carlos R. S. Milani. 2012. 'Atores não estatais e trade policy-making no Brasil: análise dos interesses e das estratégias da CEB e da REBRIP'. Dados 55 (2): 367-401.

Ortiz Mena, Antonio. 2003. 'Mexico in the WTO Debate'. FEB Briefing Papers, May.

Presidência da República. 1999. 'Decreto de 10 de Junho: Cria, no âmbito do Ministério das Relações Exteriores, o Grupo Interministerial de Trabalho sobre Comércio Internacional de Mercadorias e de Serviços, e dá Outras Providências'. Available <http://www2.camara.leg.br/legin/fed/decret_sn/ 1999/decreto-8-10-junho-1999-377585-publicacaooriginal-1-pe.html> [Accessed 20 February 2014].

Ramanzini Júnior, Haroldo and Rogério de Souza Farias. 2014. 'A sociedade, o Estado e a política externa: em busca de sintonia'. Política Externa 23 (2): 173-181.

REBRIP (Rede Brasileira de Integração dos Povos). 2014. 'GT Serviços'. Available < http://www.rebrip.org.br/grupos_trabalho/64/gt-servicos> [Accessed 16 April 2014]. 


\section{Vinícius Rodrigues Vieira}

Renn, Ortwin, Thomas Webler and Hans Kastenholz. 1996. 'Procedural and Substantive Fairness in Landfill Siting: A Swiss Case Study', Risk: Health, Safety and Environment 7: 145-68.

Risse, Thomas. 2002. 'Transnational Actors and World Politics', in Walter Carlsnaes, Thomas Risse and Beth A. Simmons (eds), Handbook of International Relations, London: Sage. pp. 426-452.

Rodrigues Vieira, Vinícius. 2014. The Players in the Fields: National Identity and the Politics of Domestic Interests of Brazil and India in the Doha Development Round (2001-08). Thesis - Doctorate in International Relations. Nuffield College, University of Oxford.

Saguier, Marcelo. 2011. 'Transnational Labour Mobilisation in the Americas,' in David Armstrong, Valeria Bello, Julie Gilson and Debora Spini (eds), Civil Society and International Governance: The Role of Non-State Actors in Global and Regional Regulatory Frameworks, London and New York: Routledge. pp. 181-197.

Sande, Camila. Interviewed by: Author (27 June 2012).

Scharpf, Fritz W. 1999. Governing in Europe: Effective and Democratic? Oxford: Oxford University Press.

Schmidt, Vivien A. 2006. Democracy in Europe: The EU and National Polities. Oxford: Oxford University Press.

2010. 'Democracy and Legitimacy in the European Union Revisited: Input, Output and Throughput'. KFG Working Paper Series, No. 21, November, Kolleg-Forshergruppe (KFG) 'The Transformative Power of Europe' Freie Universität Berlin.

Schneider, Ben Ross. 1997. 'Big Business and the Politics of Economic Reform: Confidence and Concentration in Brazil and Mexico,' in Ben Ross Schneider and Sylvia Maxfield (eds), Business and the State in Developing Countries, Ithaca: Cornell University Press. pp. 191-215.

Senior Bureaucrat. Interviewed by: Author (18th October 2012).

Smith, Jackie. 2008. Social Movements for Global Democracy. Baltimore: Johns Hopkins University Press.

Steffek, Jens and Ulrike Ehling. 2008. 'Civil Society Participation at the Margins: The Case of the WTO', in Jens Steffek, Claudia Kissling and Patrizia Nanz (eds), Civil Society Participation in European and Global Governance: A Cure for the Democratic Deficit? Basingstoke, UK: Palgrave. pp. 95-115. 


\section{When Procedural Legitimacy Equals Nothing: \\ Civil Society and Foreign Trade Policy...}

Tallberg, Jonas and Anders Uhlin. 2012. 'Civil Society and Global Democracy: an Assessment', in Daniele Archibugi, Mathias Koenig-Archibugi and Raffaele Marchetti (eds), Global Democracy: Normative and Empirical Perspectives, Cambridge: Cambridge University Press. pp. 201-232.

Torres, Bianca. 2001. 'La Academia Mexicana y la Formulación y Puestar en Práctica de la Política Comercial en Mexico'. In Mercedes Botto (ed), Saber y Política en América Latina: El uso del conocimiento en las negociaciones comerciales internacionales, Buenos Aires: Prometeo Libros and Flacso Argentina. pp. 129-162.

Vigevani, Tullo, Gustavo de Mauro Favaron, Haroldo Ramanzini Jr. and Rodrigo Alves Correia. 2008. 'O papel da integração regional para o Brasil: universalismo, soberania e percepção das elites', Revista Brasileira de Política Internacional 51 (1): 5-27.

Villamar, Alejandro. 2015. 'Guerra de Inusitadas Presiones em el TPP'. Available at <http://www.rmalc.org/guerra-de-inusitadas-presiones-en-eltpp/> [Accessed 07 Oct 2015].

Witker, Jorge and Laura Hernández. 2008. Régimen Jurídico del Comercio Exterior de México. Mexico, DF: Universidad Nacional Autónoma de México.

WTO (World Trade Organization). 2009. 'NGOs Attendance to the WTO Sixth Ministerial Conference, Hong Kong, China, 13-18 December, 2005' . Available at: <https://www.wto.org/english/thewto_e/minist_e/min05_e/list_ngo_ hk05_e.pdf> [Accessed 14 Oct 2015].

\section{Notes}

1. As Beer et al. (2012: 328) argue, if, on the one hand, the growing relevance of international mechanisms of governance empowered CSOs, on the other the expansion of market de-regulation and other economic practices labelled as neoliberal mitigated the state capacity to create mechanisms of social protection and, thus, the power of those organisations in affecting policymaking.

2. A common argument State actors use to ignore demands from CSOs and OSMs lies in their supposed lack of representativeness (International Trade Centre 2015). 


\section{About the Author}

Vinícius Rodrigues Vieira is a Lecturer in International Relations at the School of Social Sciences of Getúlio Vargas Foundation (FGV) and a post-doctoral Researcher at the Centre for the Study of International Negotiations (CAENI) of the Institute of International Relations of the University of São Paulo (IRI-USP). He is also a Fellow (non-residential) of the Summer Program in Social Science (SPSS) of the Institute for Advanced Study, Princeton (IAS), for the period 2015-17. He holds a doctorate in International Relations from Nuffield College, University of Oxford (2014), and a M.A. in Latin American Studies from the University of California at Berkeley (2010). He has already published articles in peer-reviewed journals such as the Bulletin of Latin American Research and the Journal of International Relations and Development. 